\title{
A Study to Assess the Effect of Stress on Mental Balance/ Judgement, Psychological Health and Adjustment Level
}

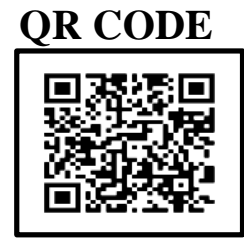

\section{MOHITA SINGH ${ }^{1}$, SUNIL SACHDEV ${ }^{* 2}$ (D)}

BACKGROUND AND AIM: Stress acts as a warning signal generated in the brain by detecting danger in the environment and indicating that action is required immediately. Only when this regulatory mechanism fails to function properly and promptly, stress inflicts abnormal pathological conditions (e.g. anxiety disorders or depression) interfering with healthy well-being. Present study was designed to study the effect of stress on judgment, adjustment and various aspects of psychological health.

MATERIALS AND METHOD: The study was done on 90 subjects (medical students) chosen randomly with no gender bias. Baseline parameters of mental balance/ judgment, adjustment level and various parameters of psychological health were recorded during mid-semester when there was no exam pressure. The parameters were again studied one to two week before exams. Parameters were compared from their baseline values. The student's t-test was used to compare baseline values from during stress values. $\mathrm{p}$ value was significant when $\mathrm{p} \leq 0.05$.

RESULTS: Students reported significant decrease in judgment level and their adjustment level showed tendency to decrease during stress. Also, there was significant increase to fall into disorders of anxiety and depression. Other aspects of psychological health showed variable response to stress.

CONCLUSION: Stress has impact on judgment, adjustment and psychological health.

\section{INTRODUCTION}

Stress is a psychological pain that may be harmful or beneficial depending upon the degree of stress. Stress in small amount enhances performance, act as motivating factor for adaptation and reaction to environment. ${ }^{1}$ In excessive amount, stress leads to bodily harm such as increased risk of stroke, heart attack, ulcers and mental illness (depression). ${ }^{2}$ Stress is related to both internal and external factors. External factors are usually related to environment. ${ }^{3}$ Internal factors cause an individual to experience anxiety, negative emotions surrounding a situation such as pressure, discomfort, etc. ${ }^{1}$ Stress is mostly due to inability in coping with obstacles (stimuli, people, situations, etc.). When people think that the demands being placed on them exceed their ability to cope, then they perceive stress. ${ }^{4}$

Stress can be good [eustress] or bad [distress]. It may be in excessive amount [hyperstress] or in fewer amounts [hypostress]. For a productive lifestyle, good stress and a perfect balance between excess and less amount of stress is required..$^{-6}$ The response to stress varies at individual level. Much of it depends on individual's personality, childhood experiences with major stresses and trauma and also depends on the genetic makeup of an individual. ${ }^{-9}$
Mental balance is the healthy psychological state of someone with good judgment. It is the equal integration of all mental processes. ${ }^{10}$ WHO defines mental/ psychological health as not just the absence of mental disorder but a state of well-being in which an individual realizes his/her own abilities, can cope up with normal stresses of life, can work productively and fruitfully and is able to make a contribution to his/her community. ${ }^{11}$ Mental health problems might arise due to stress, loneliness, depression, anxiety, death of loved ones, suicidal thoughts, grief, addiction, self-harm, mood disorders or other mental illness. ${ }^{12}$ Mental wellness is generally viewed as a positive attribute. It highlights emotional well-being, the capacity to live a full creative life and the flexibility to deal with life's inevitable challenges. ${ }^{13}$ Emotional well-being refers to high levels of positive emotions. The social and psychological well-being refers to the presence of social and psychological skills and abilities that contribute to optimal functioning in daily life. ${ }^{14}$

Stress and stressful encounters are inevitable and nonescapable part of life. Does exam stress effects our adjustment level in social, emotional, home, health and college fronts? Does exam stress lead to increase in incidence of psychological disorders? To answer these 
intriguing questions, the present study was designed to study the effect of stress on mental balance/judgment, psychological health and adjustment level has been studied.

\section{MATERIALS AND METHOD}

The study was conducted on 90 subjects (medical students) chosen randomly with no gender bias on volunteer basis (age $20-29$ years; mean \pm SD, $23.42 \pm$ 1.6). Subjects with past or present significant history, psychiatric illness, CNS disorder, drug or alcohol abuse and any other known medical conditions were excluded. Subjects were arbitrarily assigned numbers for the sake of convenience and quick reference in the results and discussion. Complete anonymity was maintained to ensure that subjects comfortably gave honest responses. Each subject was its own control.

\section{Inclusion criteria for the subjects}

- Age 20-29 years.

- No significant medical history based on a short clinical interview.

\section{Exclusion criteria for the subjects}

- Past or present significant history.

- Psychiatric illness.

- CNS disorder including traumatic brain injury.

- Drug or alcohol abuse, asthma, immune disorders, hypertension, seizures, corticosteroid treatment, or any other known medical condition.

Median value was taken as cut off on basis of which subjects were divided into high and low judgment groups (median split method). For various psychological parameters, scores obtained during test were used to divide the subjects into good psychological health, normal status and poor psychological health groups. The scale used were: For mental balance/judgment: PGI Memory Scale ${ }^{15}$; for psychological health: ANDI scale ${ }^{16}$ and for adjustment level: Adjustment inventory. ${ }^{17}$ The subjects were called and briefed about the study and informed written consent for participation was taken. The basal parameters were studied during mid-semester to ensure that there was no examination stress. The parameters were again recorded one to two weeks prior to exams to study the effect of stress on the same parameters. Comparison was made between two values.

\section{STATISTICAL ANALYSIS}

The results were computed using stats tester version 3.1.2. The test of significance used to compare the results in both groups was student $\mathrm{t}$ test with $\mathrm{p}$ value $<$ 0.05 being considered as significant $\left({ }^{*}\right), \mathrm{p}<0.01$ as more significant $\left({ }^{* *}\right)$ and $\mathrm{p}<0.001$ as highly significant $\left({ }^{* * *}\right)$.

\section{RESULTS}

The effect of stress on judgment lead to division of subjects into high and low judgment group. Both high and low judgment groups exhibited significant response to exam stress. Also, adjustment level showed tendency to decrease during stress though it was nonsignificant (Table $1 \&$ Figure 1 ).

The effect of stress on various components of psychological health lead to division of subjects into three groups. These were poor psychological health (Group 1), normal status (Group 2) and good psychological health (Group 3). The different components of psychological health studied exhibited variable results to stress [Table 2 (a)-(g)].

\begin{tabular}{|c|c|c|c|c|}
\hline $\begin{array}{l}\text { S. } \\
\text { No }\end{array}$ & GROUPS & $\begin{array}{l}\text { BASAL } \\
\text { VALUE }\end{array}$ & $\begin{array}{l}\text { DURING } \\
\text { STRESS }\end{array}$ & $\begin{array}{c}p \\
\text { VALUE }\end{array}$ \\
\hline 1 & \multicolumn{4}{|c|}{ JUDGEMENT GROUPS } \\
\hline (i) & $\begin{array}{c}\text { HIGH } \\
\text { JUDGMENT } \\
{[\mathrm{n}=47]}\end{array}$ & $8.48 \pm 0.49$ & $6.85 \pm 1.42$ & $\underset{* *}{0.000^{*}}$ \\
\hline $\mathbf{A}$ & $\begin{array}{c}\text { Decrease } \\
{[\mathrm{n}=33]}\end{array}$ & $8.69 \pm 0.45$ & $6.18 \pm 1.14$ & $\begin{array}{c}0.000^{*} \\
* *\end{array}$ \\
\hline$\overline{\mathbf{B}}$ & $\begin{array}{c}\text { Increase } \\
{[\mathrm{n}=14]}\end{array}$ & $8.00 \pm 0.00$ & $8.42 \pm 0.49$ & $\underset{*}{0.004^{*}}$ \\
\hline (ii & $\begin{array}{c}\text { LOW } \\
\text { JUDGMENT } \\
{[\mathrm{n}=43]}\end{array}$ & $6.23 \pm 0.77$ & $4.44 \pm 2.11$ & $\begin{array}{c}0.000^{*} \\
* *\end{array}$ \\
\hline $\mathbf{A}$ & $\begin{array}{l}\text { Decrease } \\
{[\mathrm{n}=35]}\end{array}$ & $6.14 \pm 0.79$ & $3.62 \pm 1.35$ & $\underset{* *}{0.000 *}$ \\
\hline $\mathbf{B}$ & $\begin{array}{c}\text { Increase } \\
{[\mathrm{n}=8]}\end{array}$ & $6.62 \pm 0.48$ & $8.00 \pm 0.70$ & $\begin{array}{c}0.000^{*} \\
* *\end{array}$ \\
\hline \multirow[t]{2}{*}{2} & \multicolumn{4}{|c|}{ ADJUSTMENT LEVEL } \\
\hline & & $\begin{array}{c}246.06 \pm \\
47.28\end{array}$ & $\begin{array}{c}243.12 \pm \\
47.39\end{array}$ & 0.67 \\
\hline
\end{tabular}

Table 1. Basal and during stress values of judgment and adjustment level

\section{DISCUSSION}

Stress is an inevitable part of life. Both the stressful life events and daily life stresses have deleterious and cumulative effects on human body and brain functions. The present study reported significant decrease in judgement level in both groups. There was nonsignificant decrease in adjustment level under stress. 


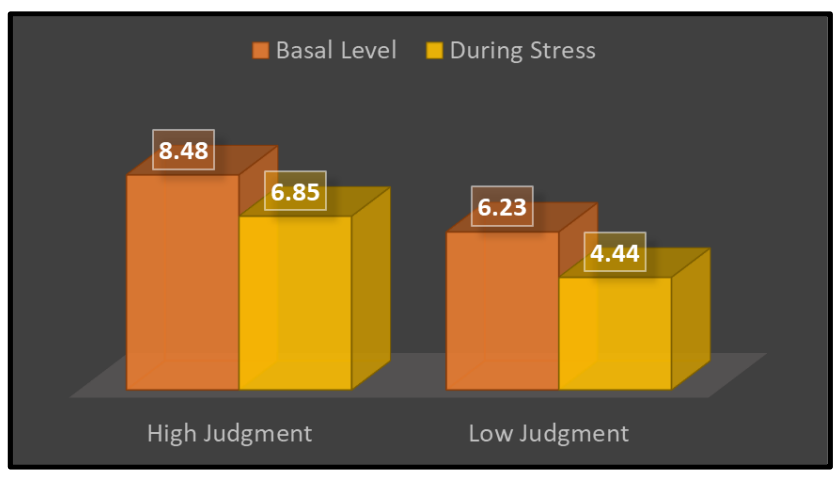

Figure 1. High and Low Judgement Groups

\begin{tabular}{|c|c|c|c|}
\hline GROUPS & $\begin{array}{l}\text { BASAL } \\
\text { VALUE }\end{array}$ & $\begin{array}{l}\text { DURING } \\
\text { STRESS }\end{array}$ & $\underset{\text { VALUE }}{\mathbf{p}}$ \\
\hline $\begin{array}{c}\text { Group 1: Poor } \\
\text { psychological } \\
\text { health } \\
{[n=15]} \\
\end{array}$ & $\begin{array}{c}8.33 \pm \\
1.01\end{array}$ & $\begin{array}{c}8.66 \pm \\
1.19\end{array}$ & 0.43 \\
\hline $\begin{array}{c}\text { Group 2: } \\
\text { Normal status } \\
{[\mathrm{n}=32]} \\
\end{array}$ & $\begin{array}{c}5.5 \pm \\
0.5\end{array}$ & $\begin{array}{c}5.56 \pm \\
0.55\end{array}$ & 0.64 \\
\hline $\begin{array}{c}\text { Group 3: Good } \\
\text { psychological } \\
\text { health } \\
{[n=43]}\end{array}$ & $\begin{array}{c}2.46 \pm \\
0.99\end{array}$ & $\begin{array}{c}3.25 \pm \\
0.74\end{array}$ & $0.000^{* * *}$ \\
\hline
\end{tabular}

Table 2 (a). Self Esteem/ Inferiority Level of the Subjects

Various parameters of psychological health reported significant and non-significant changes.

In the present study, both increase and decrease in performance was noted in both high and low judgment groups. In high judgment group [n = 47], 33 subjects showed decrease and 14 subjects showed increase of performance. While in low judgment group [ $n=43], 35$ subjects showed decrease and 8 subjects showed increase of performance under stress. Both improved and degraded performance has been associated with increased stress. For some individuals, heightened stress elevates their performance and others are vulnerable to the negative impacts of stress, which results in diminished performance. ${ }^{18}$ In another study, the effect of stress (computerized forest fire-fighting game) on performance and judgment was analysed. Half of the subjects were placed under conditions of stress and others were left to focus on their task. The researchers found that subjects under stress performed equally to those not stressed, but their

\begin{tabular}{|c|c|c|c|c|}
\hline S.NO & GROUPS & $\begin{array}{l}\text { BASAL } \\
\text { VALUE }\end{array}$ & $\begin{array}{l}\text { DURING } \\
\text { STRESS }\end{array}$ & $\underset{\text { VALUE }}{\mathbf{p}}$ \\
\hline 1 & $\begin{array}{c}\text { Group 1: Poor } \\
\text { psychological } \\
\text { health } \\
{[n=19]}\end{array}$ & $\begin{array}{c}8.15 \pm \\
1.08\end{array}$ & $\begin{array}{c}8.42 \pm \\
1.18\end{array}$ & 0.49 \\
\hline 2 & $\begin{array}{l}\text { Group 2: } \\
\text { Normal } \\
\text { status } \\
{[\mathrm{n}=54]}\end{array}$ & $\begin{array}{c}5.42 \pm \\
0.49\end{array}$ & $\begin{array}{c}6.85 \pm \\
1.33\end{array}$ & $0.000^{* * *}$ \\
\hline A & $\begin{array}{c}\text { Deteriorated } \\
\text { to group } 1 \\
{[\mathrm{n}=30]}\end{array}$ & $\begin{array}{c}5.43 \pm \\
0.49\end{array}$ & $\begin{array}{c}7.83 \pm \\
0.93\end{array}$ & $0.000^{* * *}$ \\
\hline B & $\begin{array}{l}\text { Remained in } \\
\text { group } 2 \\
{[n=24]}\end{array}$ & $\begin{array}{c}5.41 \pm \\
0.49\end{array}$ & $\begin{array}{c}5.62 \pm \\
0.48\end{array}$ & 0.15 \\
\hline 3 & $\begin{array}{c}\text { Group 3: } \\
\text { Good } \\
\text { psychological } \\
\text { health } \\
{[n=17]}\end{array}$ & $\begin{array}{c}2.41 \pm \\
1.03\end{array}$ & $\begin{array}{c}4.82 \pm \\
1.72\end{array}$ & $0.000^{* * *}$ \\
\hline A & $\begin{array}{l}\text { Deteriorated } \\
\text { to group } 1 \\
{[\mathrm{n}=3]}\end{array}$ & $\begin{array}{c}2.66 \pm \\
1.24\end{array}$ & $\begin{array}{c}7.66 \pm \\
0.94\end{array}$ & $0.01^{* *}$ \\
\hline B & $\begin{array}{c}\text { Deteriorated } \\
\text { to group } 2 \\
{[\mathrm{n}=6]}\end{array}$ & $\begin{array}{c}1.83 \pm \\
0.68\end{array}$ & $\begin{array}{c}5 \cdot 33 \pm \\
0.47\end{array}$ & $0.000^{* * *}$ \\
\hline C & $\begin{array}{l}\text { Remained in } \\
\text { group } 3 \\
{[\mathrm{n}=8]}\end{array}$ & $\begin{array}{c}2.75 \pm \\
0.96\end{array}$ & $\begin{array}{c}3.37 \pm \\
0.69\end{array}$ & 0.18 \\
\hline
\end{tabular}

Table 2 (b). Happiness/ Depression Level of the Subjects

problem solving patterns were different. Stressed subjects focused on the general outline of the problem, while non-stressed individuals relied on in-depth analysis. Consequently, stressed subjects made fewer errors in setting priorities while non-stressed subjects controlled their fire-fighting game operations better. ${ }^{19}$

The present study reported decrease in adjustment level during stress though it was not significant. Another study on adjustment level and academic stress reported inverse and no significant relation between them though level of adjustment influenced the number of stressful events and stress experienced. ${ }^{20}$ Adjustment depends on fulfilment of significant needs (physical, emotional, social, intellectual, moral and vocational). ${ }^{21}$ Negligence of parents, high expectations in academic and other performances, abused childhood, growing up tensions etc. are few listed causes of stress. Parents who are not emotionally available for their children or lack of positive coping 
mechanism themselves often spur stress in their offspring. Stressed children show signs of emotional disabilities, aggressive behaviour, shyness, social phobias and lack interest in otherwise enjoyable activities. $^{22}$

\begin{tabular}{|c|c|c|c|c|}
\hline S.NO & GROUPS & $\begin{array}{l}\text { BASAL } \\
\text { VALUE }\end{array}$ & $\begin{array}{l}\text { DURING } \\
\text { STRESS }\end{array}$ & $\begin{array}{c}\mathbf{p} \\
\text { VALUE }\end{array}$ \\
\hline 1 & $\begin{array}{c}\text { Group 1: Poor } \\
\text { psychological } \\
\text { health } \\
{[\mathrm{n}=11]}\end{array}$ & $\begin{array}{c}7.72 \pm \\
0.96\end{array}$ & $\begin{array}{c}8.72 \pm \\
0.96\end{array}$ & $0.03^{*}$ \\
\hline 2 & $\begin{array}{c}\text { Group 2: } \\
\text { Normal } \\
\text { status } \\
{[\mathrm{n}=14]}\end{array}$ & $\begin{array}{c}5.42 \pm \\
0.49\end{array}$ & $\begin{array}{c}6.35 \pm \\
1.28\end{array}$ & $0.02^{*}$ \\
\hline $\mathbf{A}$ & $\begin{array}{c}\text { Deteriorated } \\
\text { to group } 1 \\
{[\mathrm{n}=4]}\end{array}$ & $\begin{array}{c}5.5 \pm \\
0.5\end{array}$ & $8.0 \pm 1.22$ & $0.01^{* *}$ \\
\hline B & $\begin{array}{l}\text { Remained in } \\
\text { group } 2 \\
{[\mathrm{n}=10]}\end{array}$ & $\begin{array}{l}5.4 \pm \\
0.48\end{array}$ & $5.7 \pm 0.45$ & 0.19 \\
\hline 3 & $\begin{array}{c}\text { Group 3: } \\
\text { Good } \\
\text { psychological } \\
\text { health } \\
{[\mathrm{n}=65]}\end{array}$ & $\begin{array}{c}2.46 \pm \\
0.97\end{array}$ & $\begin{array}{c}5.30 \pm \\
1.94\end{array}$ & $0.000^{* * *}$ \\
\hline $\mathbf{A}$ & $\begin{array}{c}\text { Deteriorated } \\
\text { to group } 1 \\
{[\mathrm{n}=18]}\end{array}$ & $\begin{array}{c}2.77 \pm \\
0.91\end{array}$ & $\begin{array}{c}7.66 \pm \\
0.88\end{array}$ & $0.000^{* * *}$ \\
\hline B & $\begin{array}{c}\text { Deteriorated } \\
\text { to group } 2 \\
{[n=27]}\end{array}$ & $\begin{array}{c}2.25 \pm \\
0.96\end{array}$ & $\begin{array}{c}5.44 \pm \\
0.49\end{array}$ & $0.000^{* * *}$ \\
\hline$C$ & $\begin{array}{l}\text { Remained in } \\
\text { group } 3 \\
{[\mathrm{n}=\mathbf{2 0}]}\end{array}$ & $\begin{array}{c}2.45 \pm \\
0.97\end{array}$ & $3.0 \pm 0.94$ & 0.08 \\
\hline
\end{tabular}

The present study reported significant increase in inferiority complex during stress among good psychological health students while rest two groups showed non-significant changes with tendency to increase. Earlier studies reported positive correlation between inferiority complex, frustration level and academic performance. ${ }^{23}$

The present study reported both significant and nonsignificant changes in various groups between baseline and during stress value in happiness depression and anxiety/calmness level. Earlier studies reported that stress, anxiety and depression exist among all medical students. ${ }^{24}$ These baseline traits of anxiety, depression and stress increased among students as the exams approached nearer. ${ }^{25}$ Students adopted exam related trait emotions i.e anxiety, depression, hopelessness, anger as a method of coping style for examination stress. ${ }^{26}$

\begin{tabular}{|c|c|c|c|}
\hline GROUPS & $\begin{array}{l}\text { BASAL } \\
\text { VALUE }\end{array}$ & $\begin{array}{c}\text { DURING } \\
\text { STRESS }\end{array}$ & $\underset{\text { VALUE }}{\mathbf{p}}$ \\
\hline $\begin{array}{c}\text { Group 1: Poor } \\
\text { psychological health } \\
{[n=20]}\end{array}$ & $\begin{array}{c}8.05 \pm \\
1.02\end{array}$ & $\begin{array}{c}8.85 \pm \\
1.01\end{array}$ & $0.02^{* *}$ \\
\hline $\begin{array}{c}\text { Group 2: Normal } \\
\text { status } \\
{[\mathbf{n}=37]}\end{array}$ & $\begin{array}{c}5.37 \pm \\
0.48\end{array}$ & $\begin{array}{c}5.54 \pm \\
0.64\end{array}$ & 0.22 \\
\hline $\begin{array}{c}\text { Group 3: Good } \\
\text { psychological health } \\
{[\mathbf{n}=33]}\end{array}$ & $\begin{array}{c}2.54 \pm \\
1.01\end{array}$ & $\begin{array}{c}3.33 \pm \\
0.94\end{array}$ & $0.000^{* * *}$ \\
\hline
\end{tabular}

Table 2 (d). Naturality/ Obsessiveness Level of the Subjects

\begin{tabular}{|c|c|c|c|}
\hline GROUPS & $\begin{array}{l}\text { BASAL } \\
\text { VALUE }\end{array}$ & $\begin{array}{l}\text { DURING } \\
\text { STRESS }\end{array}$ & $\stackrel{p}{\mathbf{p}}$ \\
\hline $\begin{array}{c}\text { Group 1: Poor } \\
\text { psychological health } \\
{[\mathbf{n}=21]}\end{array}$ & $\begin{array}{c}8.14 \pm \\
1.03\end{array}$ & $\begin{array}{c}8.90 \pm \\
1.06\end{array}$ & $0.02^{*}$ \\
\hline $\begin{array}{c}\text { Group 2: Normal } \\
\text { status } \\
{[\mathbf{n}=39]}\end{array}$ & $\begin{array}{c}5.41 \pm \\
0.49\end{array}$ & $\begin{array}{c}5.66 \pm \\
0.56\end{array}$ & $0.03^{*}$ \\
\hline $\begin{array}{c}\text { Group 3: Good } \\
\text { psychological health } \\
{[\mathrm{n}=30]}\end{array}$ & $\begin{array}{l}2.3 \pm \\
1.00\end{array}$ & $\begin{array}{c}3.43 \pm \\
0.76\end{array}$ & $0.000^{* * *}$ \\
\hline
\end{tabular}

Table 2 (e). Independence/ Dependence Level of the Subjects

\begin{tabular}{|c|c|c|c|}
\hline GROUPS & $\begin{array}{l}\text { BASAL } \\
\text { VALUE }\end{array}$ & $\begin{array}{l}\text { DURING } \\
\text { STRESS }\end{array}$ & $\stackrel{p}{\text { VALUE }}^{p}$ \\
\hline $\begin{array}{c}\text { Group 1: Poor } \\
\text { psychological } \\
\text { health } \\
{[\mathbf{n}=27]} \\
\end{array}$ & $\begin{array}{c}8.51 \pm \\
1.13\end{array}$ & $\begin{array}{c}8.77 \pm \\
1.22\end{array}$ & 0.43 \\
\hline $\begin{array}{c}\text { Group 2: Normal } \\
\text { status } \\
{[n=42]} \\
\end{array}$ & $\begin{array}{c}5.40 \pm \\
0.49\end{array}$ & $\begin{array}{c}5 \cdot 57 \pm \\
0.49\end{array}$ & 0.12 \\
\hline $\begin{array}{c}\text { Group 3: Good } \\
\text { psychological } \\
\text { health } \\
{[\mathbf{n}=2 \mathbf{2}]}\end{array}$ & $\begin{array}{c}2.28 \pm \\
0.93\end{array}$ & $3.0 \pm 1.02$ & $0.02^{*}$ \\
\hline
\end{tabular}

Table 2 (f). Healthy/ Hypochondriasis Level of the Subjects

Present study reported significant increase in obsessiveness level under stress. Studies show that stress has role in aetiology and maintenance of symptoms of OCD and that stress can predispose towards or exacerbate symptoms of OCD. People with OCD often identify stress as factor that exacerbates their symptoms and many trace the onset of symptoms to the stressful period of life. ${ }^{27}$ 


\begin{tabular}{|c|c|c|c|}
\hline GROUPS & \multicolumn{1}{c}{ BASAL } & $\begin{array}{c}\text { DURING } \\
\text { VALUE }\end{array}$ & $\begin{array}{c}\text { p } \\
\text { STRESS }\end{array}$ \\
VALUE
\end{tabular}

Table 2 (g). Innocence/Guilt Feeling Level of the Subjects

The present study reported significant increase in interpersonal dependence level under stress. Persons differ in their vulnerability to different types of stressful life events that determines whether their self-worth is primarily dependent on interpersonal relations (sociotropy/ dependency) or achievement (selfcriticism/ autonomy). ${ }^{28}$

Also, there was significant increase in state of hypochondriasis under stress in good psychological health group and rest two groups reported nonsignificant changes with tendency to increase. Studies have reported that hypochondriasis is more related to anxiety disorder than somatization or depressive disorder. ${ }^{29}$ The pre-examination phase is an inescapable period of each student's life and there is an increase in anxiety symptoms during this phase..$^{30}$

Present study reported no significant increase in guilt level under stress though there was tendency to increase. Studies report that guilt experienced in response to traumatic/ stressful event may lead to development of stress disorder. ${ }^{31}$

\section{Limitations of the study}

The present study was performed with small sample size for assessing the effect of stress on judgment, psychological health and adjustment level. The results of the study maybe specific to the type of subject chosen and individual variation in genetic make up to handle stressful situations. However, the study gave us important insight into the fact that stress does have impact on above mentioned parameters. Further studies need to look at the effect of stress in larger number of subjects.

\section{CONCLUSION}

Stress inflicts error in judgment and to some extent enhancement in performance. On the whole, stress leads to poor emotional, social and psychological wellbeing and adjustment level.

This work is an original article and no financial grants were obtained from any source. There are no conflict of interests.

\section{REFERENCES}

1. Simandan D. On how much one can take: relocating exploitation and exclusion within the broader framework of allostatic load theory. Hlth Plc. 2010;16(6):1291-3.

2. Sapolsky, Robert M. Why Zebras Don't Get Ulcers? St Martins Press, NY 2004: pp 37, 71, 92, 271.

3. Jones F, Bright J, Clow A. Stress: myth, theory and research. Pearson Edu 2001: pp 4.

4. Folkman S. Stress: appraisal and coping. In Encyclopaedia of behavioural medicine. Springer NY 2013: pp 1913-15.

5. Hans S. The stress concept: Past, present and future. In Cooper CL Stress research issues for the eighties. John Wiley Son 1983: pp 1-20.

6. Hans S. Implications of stress concept. NY State J Med 1975;75:2139-45.

7. Jeronimus BF, Riese H, Sanderman R, Ormal J. Mutual reinforcement between neuroticism and life experiences: A five-wave, 16 year study to test reciprocal causation. J Persty Soc Psych. 2014;107(4):751-64.

8. Jeronimus BF, Ormel J, Aleman A, Penninx BWJH, Riese $\mathrm{H}$. Negative and positive life events are associated with small but lasting change in neuroticism. Psychology Medicine 2013;43(11):2403-15.

9. Schneiderman N, Ironson G, Seigel SD. Stress and health: psychological, behavioural and biological determinants. Ann Rev Of Clin Psych 2005;1:607-28.

10. Nugent A, Pam MS. Mental Balance. Psych Dict 2013. 11. Newman T. What is mental health? MNT 2017 https://psychologydictionary.org/mental-balance [Last Accessed on $15^{\text {th }}$ August, 2019]

12. Kitchener B, Jorm A. mental health first aid manual. Canberra: Ctr Mental Hlth Res 2002:pp 5.

13. Graham MC. Facts of life: ten issues of contentment. Outskirts Press 2014:pp 6-10.

14. Joshanloo M. Revisiting the empirical distinction between hedonic and eudaimonic aspects of well-being using exploratory structural equation modelling. J Happ Stud 2015; 17(5):2023-36.

15. Pershad D, Wig NN. Reliability and validity of a new 
battery of memory tests. Ind J Psy. 1978;20:76-80. 16. Singh RM, Bhargava M. Adjustment Neuroticism Dimensional Inventory. Ntl Psychol Corp 1983. 17. Saxena MSL. Adjustment Inventory. Prasad Psycho Corp 2010.

18. Poulton EC. Arousing environmental stresses can improve performance, whatever people say. Avn Spac Envir Medicine 1976; 47: 1193-1204.

19. Dorner D, Pfeifer F. Strategic thinking and stress. Ergon 1993; 36(11):1345-60.

20. Tung S, Chahal N. Relationship between stress and adjustment adolescent females: A casual study. J Persty Study Grp Behav 2005;25:19-31

21. Aggarwal JC. Psychology of learning and development. Shipra Publishers 2004.

22. Hussain A, Kumar A, Husain A. Academic stress and adjustment among high school students. J Ind Acad of Psych 2008; 34:70-3.

23. Kenchappanavar RN. Relationship between inferiority complex and frustration in adolescent. J Humn Soc Sci 2012;2(2):1-5.

24. El-Gilany AH, Amr M, Hammad S. Perceived stress among male medical students in Egypt and Saudi Arabia: Effect of sociodemographic factors. Ann Saudi Med. 2008;28:442-8.
25. Kulsoom B, Afsar NA. Stress, anxiety and depression among medical students in multiethnic setting. Neuropsychaitr Dis Treat 2015;11:1713-22.

26. Spangler G, Pekrun R, Kramer K, Hofmann H. Student's emotions, physiological reactions and coping in academic exams. J Anx Stress Cope 2010;15(4):413-32. 27. Adams TG, Kelmendi B, Brake A, Gruner P, Badour $\mathrm{CL}$, Pittenger $\mathrm{C}$. The role of stress in pathogenesis and maintenance of OCD. Chronic Stress (Thousand Oaks) 2018;2. doi: 10.1177/2470547018758043.

28. Blatt SJ, D'Affliti JP, Quinlan DM. Experiences of depression in normal young adults. J Abnorm Psychol 1976; 85:383-9.

29. Scarella TM, Laferton JAC, Ahern DK, Fallon BA, Barsky A. The relationship of hypochondriasis to anxiety, depression and somatoform disorders. Psychosomatics 2016; 57(2):200-7.

30. Yadav P, Chauhan VS, Bhat PS, Agarwal N, Yadav C, Bhatia S. Cross section study of anxiety symptoms in students in pre-examination period. Ind Psychiatry J 2017; 26(1):56-63.

31. Bub K, Lommen MJJ. The role of guilt in posttraumatic stress disorder. Eur J Psychotraumatol 2017; 8(1):1407202.
Source of support: Nil, Conflict of interest: None declared

\section{AUTHOR AFFILIATIONS: (*Corresponding Author)}

1. Demonstrator (ORCID ID: https://orcid.org/oooo-00o3-2853-6782)

2. *Professor \& Head, Department of Physiology (ORCID ID: https://orcid.org/oooo-ooo1-5401-2419) Government Medical College (GMC), Jammu
Cite this article as:

Singh M, Sachdev S. A Study to Assess the Effect of Stress on Mental Balance/ Judgement,

Psychological Health and Adjustment Level. Int Healthc Res J. 2019;3(9):303-308. https://doi.org/10.26440/IHRJ/0309.12306 